\title{
Identification of anti-tumor components from toad venom
}

\author{
FEI GAO ${ }^{1,2}$, XIANGJUN WANG ${ }^{1}$, ZHAO LI $^{1}$, AICUN ZHOU $^{1}$, \\ EVELYN TIFFANY-CASTIGLIONI ${ }^{3}$, LIJUN XIE $^{4}$ and YONGCHANG QIAN ${ }^{1,3}$
}

\author{
${ }^{1}$ Department of Traditional Chinese Medicine, Zhejiang A\&F University; \\ ${ }^{2}$ Nurturing Station for the State Key Laboratory of Subtropical Silviculture, School of Forestry and Biotechnology, \\ Zhejiang A\&F University, Lin'An, Zhejiang 311300, P.R. China; ${ }^{3}$ Department of Veterinary Integrative Biosciences, \\ Texas A\&M University, College Station, TX 77843, USA; ${ }^{4}$ Department of Orthopedics, 2nd Affiliated \\ Hospital, School of Medicine, Zhejiang University, Hangzhou, Zhejiang 310052, P.R. China
}

Received January 24, 2016; Accepted December 2, 2016

DOI: $10.3892 / \mathrm{ol} .2017 .6160$

\begin{abstract}
Secretion of granular glands from the skin of amphibians is a fascinating resource of active substances, particularly for cancer therapy in clinical practice of Traditional Chinese Medicine. A variety of anti-tumor peptides have been isolated from different toads and frogs; however, no anti-tumor peptides are reported in toad venom of Bufo gargarizans. Firstly, soluble fraction from fresh toad venom (FTV) was compared with that from dried toad venom (DTV), using HPLC analysis. It was revealed that FTV has a different HPLC chromatography compared with DTV. Soluble fraction of FTV is more toxic to SH-SY5Y cells than that of DTV, as evaluated by MTT assay. Secondly, it was identified that protein components from soluble fractions of FTV and DTV possess different patterns by SDS-PAGE analysis, and proteins from FTV are also more toxic than that from DTV. Thirdly, an immobilized basic fibroblast growth factor (bFGF) affinity column was used to isolate bFGF-binding components from soluble fraction of FTV, and it was identified that bFGF-binding components prohibited bFGF-dependent neurite growth of SH-SY5Y cells. Finally, it was identified that bFGF-binding components activated apoptosis via upregulation of caspase-3 and caspase-8 expression in SH-SY5Y cells. These data suggest that FTV contains active components that interact with bFGF and activate apoptosis in SH-SY5Y cells.
\end{abstract}

Correspondence to: Professor Yongchang Qian, Department of Veterinary Integrative Biosciences, Texas A\&M University, MS 4458, College Station, TX 77843, USA

E-mail: qian3906@zafu.edu.cn; uqian@cvm.tamu.edu

Dr Lijun Xie, Department of Orthopedics, 2nd Affiliated Hospital, School of Medicine, Zhejiang University, 88 Jiefang Road, Hangzhou, Zhejiang 310052, P.R. China

E-mail: rainno@hotmail.com

Key words: toad venom, bFGF-binding component, cytotoxicity, apoptosis, SH-SY5Y cells

\section{Introduction}

As a traditional Chinese medicine (TCM), the dried secretion from skin glands of Bufo gargarizans (toad venom) has been used in the treatment of various types of inflammation in China for thousands of years (1). Previous studies reported that toad venom has an activity in tumor inhibition. For instance, extraction of toad venom inhibited the growth of non-small cell lung cancer $(2,3)$. Active components of toad venom, including telocinobufagin, marinobufagin, bufalin, bufotalin and resibufogenin, were reported to exhibit a tumor-inhibiting activity (4-6). Bufalin and cardiotonic steroid, isolated from toad venom, were identified to cause apoptosis in human prostate and breast cancer cells by upregulating the expression of caspase family genes in tumor cells $(7,8)$. Bufalin can also suppress cell proliferation and inhibit the migration and invasion of tumor cells, although the molecular mechanisms remain unknown $(6,9,10)$. By contrast, arenobufagin, another major component of toad venom, was reported as a specific inhibitor of VEGF-mediated angiogenesis (6).

Compared with the anti-tumor activity of the aforementioned small molecules from toad venom of $B$. gargarizans, studies on the anti-tumor activity of skin secretion from other amphibians are focused on peptides that are considered to be more sensitive and/or specific than small molecules (11-14). In previous studies, a large number of anti-tumor peptides were reported from different toads and frogs (15-17). Peptides from the magainin family were isolated from African clawed frog (Xenopus laevis) skin $(18,19)$. Maganin 1 and maganin 2, two peptides with 23 amino acid residues, were reported to inhibit cell proliferation in NCI-H82 and NCI-H526 cells at a low dose $(19,20)$. Since maganin 2 has a high specific cytotoxicity, its derivative via amino acid modification has been approved as a novel medicine in cancer treatment $(21,22)$. In addition, maximin and bombinin families, identified in Bombina maxima and Bombina orientalis, were reported to inhibit the proliferation of tumor cells (23).

However, the active peptides of toad venom from $B$. gargarizans are unknown since toad venom is always prepared into the dried form from secretion of toad, a procedure that possibly denatures or damages active proteins and 
peptides. The identification and detection of possible anti-tumor peptides from skin gland secretions of B.gargarizans remains a challenge, and has not been studied. In the present study, protein components and their anti-tumor activity of fresh toad venom (FTV) were compared with those of dried toad venom (DTV). Furthermore, basic fibroblast growth factor (bFGF), one of the growth factors involved in angiogenesis in cancer metastasis (24-26), was selected as a biomarker for cancers to investigate protein components from toad venom. A bFGF-immobilized affinity column was used to capture active components that can interact with bFGF. The bFGF can inhibit the apoptosis induced by oridonin in L929 tumor cells (26), and cause tumor migration by regulating several pathways $(27,28)$. The mechanism of anti-tumor activity of active components was preliminarily studied.

\section{Materials and methods}

Collection and treatment of toad venom. FTV was collected from the Laboratory Animal Center at Zhejiang University (Hangzhou, China) according to the method recommended in Pharmacopoeia of People's Republic of China (1). To prepare soluble fraction of toad venom, $0.6 \mathrm{~g}$ of FTV was extracted with $10 \mathrm{ml}$ PBS $(0.2 \mathrm{M}, \mathrm{pH} 7.2)$ in a $15 \mathrm{ml}$ tube. The tube was incubated at $16^{\circ} \mathrm{C}$ for $4 \mathrm{~h}$ on an agitator at $210 \mathrm{rpm}$ and followed by centrifugation of $12,000 \times \mathrm{g}$ at $4^{\circ} \mathrm{C}$ for $15 \mathrm{~min}$. Supernatant was collected as soluble fraction of FTV. Another $0.6 \mathrm{~g}$ of FTV was baked at $37^{\circ} \mathrm{C}$ for $24 \mathrm{~h}$ to prepare DTV. The soluble fraction of DTV was prepared using the method described for the preparation of the soluble fraction of FTV.

Cell culture. Human SH-SY5Y-EGFP cells were purchased from Hangzhou Neuropeptide Biological Science and Technology, Inc., Ltd. (NUPTEC; Hangzhou, China) and maintained as described previously (29) with a little modification. Human SH-SY5Y, Hep G2 and HUVEC cells were purchased from Type Cell Culture Collection of the Chinese Academy of Sciences (Beijing, China). HUVEC cells were cultured in endothelial cell medium (ECM) medium (HyClone; GE Healthcare Life Sciences, Logan, UT, USA) while other cells were cultured in DMEM (HyClone; GE Healthcare Life Sciences). The two mediums were supplemented with $10 \%$ fetal bovine serum (FBS) (FBS; HyClone; GE Healthcare Life Sciences) and $0.3 \%$ penicillin-streptomycin solution (Sigma-Aldrich; Merck Millipore, Darmstadt, Germany), at $37^{\circ} \mathrm{C}$ under a $5 \% \mathrm{CO}_{2}$ and $95 \%$ air humidified atmosphere in a $\mathrm{CO}_{2}$ cell incubator (Sanyo, Moniguchi, Osaka, Japan). The medium was replaced every other day.

High-pressure liquid chromatography (HPLC) analysis. HPLC analysis of samples was performed on an Agilent 1260 Liquid Chromatographer (Agilent, Santa Clara, CA, USA). Soluble fractions from FTV and DTV were filtrated by a $0.2 \mu \mathrm{m}$ filter (Axygen; Corning, Inc., Corning, NY, USA) and $30 \mu \mathrm{l}$ of each filtrated sample was loaded onto an Agilent reverse phase (RP) C8 column (Agilent) and eluted at a flow rate of $1 \mathrm{ml} / \mathrm{min}$ in a gradient of 5\% buffer B (100\% acetonitrile) (Scharlab, Barcelona, Spain) vs. $90 \%$ buffer $\mathrm{A}\left(0.1 \% \mathrm{H}_{3} \mathrm{PO}_{4}\right.$ in water $)$ for $10 \mathrm{~min}$. Components in eluates were detected at $214 \mathrm{~nm}$.
Isolation of total proteins from soluble fraction of toad venom. Soluble fractions of FTV and DTV stored at $-80^{\circ} \mathrm{C}$ freezer were incubated on ice until they were completely thawed. In total, $24 \mathrm{ml}$ of pre-cold acetone at $-80^{\circ} \mathrm{C}$ was mixed with $6 \mathrm{ml}$ of thawed soluble fractions of FTV or DTV. The mixtures were centrifuged at $4^{\circ} \mathrm{C}, 13,400 \times \mathrm{g}$ for $10 \mathrm{~min}$. The supernatant was discarded, and subsequently, pelleted proteins were re-dissolved in $6 \mathrm{ml}$ of double distilled water.

Determination of cytotoxicity. Human SH-SY5Y-EGFP cells were seeded in 96-well plates (Corning, Inc.) at an initial density of $1.0 \times 10^{4}$ cells per well and incubated at $37^{\circ} \mathrm{C}$ for $24 \mathrm{~h}$. Cells were treated with soluble fraction of FTV and DTV, and their isolated proteins were prepared from $0,0.1625,0.325$, $0.75,1.5,3$ and $6 \mathrm{mg}$ toad venom $\mathrm{wt} / \mathrm{ml}$ at $37^{\circ} \mathrm{C}$ for $24 \mathrm{~h}$. The MTT Cell Proliferation and Cytotoxicity Assay kit (Sangon; Biotech, Co., Ltd., Shanghai, China) was used to determine cytotoxicity. MTT, whose reducing capacity indicates cellular activity, was added to each well and incubated at $37^{\circ} \mathrm{C}$ for $4 \mathrm{~h}$, according to the manufacturer's protocol. Formazan solution was added to each well to resolve MTT formazan crystals. Absorbance at $490 \mathrm{~nm}$, indicating cellular activity, was determined on a Mustiskan FC scanning multi-well spectrophotometer (Thermo Fisher Scientific, Inc., Waltham, MA, USA).

Protein analysis. For SDS-PAGE analysis, protein samples were prepared as aforementioned. The soluble fraction of FTV or DTV $(10 \mu \mathrm{l})$ were mixed with $5 \mu \mathrm{l}$ XX SDS PAGE sample loading buffers (Sangon, Biotech, Co., Ltd.) and mixtures were boiled for $5 \mathrm{~min}$. The samples were then loaded onto a $12 \%$ SDS-PAGE gel and electrophoresed for $40 \mathrm{~min}$ at $110 \mathrm{~V}$. Proteins on the gel were detected by Coomassie brilliant blue R250 staining (Ourchem, Shanghai, China).

Identification of active components. A bFGF-immobilized affinity column (NUPTEC) was used to identify active peptides from the soluble fraction of toad venom. In total, $20 \mathrm{ml}$ soluble fraction of toad venom was loaded to a bFGF affinity column and the same volume of sample was loaded to a human serum albumin (HSA) affinity column (NUPTEC) as a control. Subsequent to loading, the column was eluted by 5 column volumes of $50 \mathrm{mM}$ Tris- $\mathrm{HCl}$ buffer $(\mathrm{pH}$ 7.2) and $50 \mathrm{mM}$ PBS (pH 6.0) in order, followed by elution of 3 column volumes of $100 \mathrm{mM}$ glycine buffer ( $\mathrm{pH}$ 3.0) for active components. To identify active components, an Agilent 1260 HPLC system was used to detect absorbance at $214 \mathrm{~nm}$. Collected eluates from affinity columns were loaded onto an Agilent $\mathrm{C}-8$ column and eluted at the flow rate of $1 \mathrm{ml} / \mathrm{min}$ using a $3 \%$ buffer B (100\% acetonitrile) against a $97 \%$ buffer $\mathrm{A}(0.1 \%$ $\mathrm{H}_{3} \mathrm{PO}_{4}$ in water) for $10 \mathrm{~min}$.

bFGF-inhibiting assay of bFGF-binding components. SH-SY5Y cells $\left(1 \times 10^{4}\right)$ were plated into 96 -well plates in triplicate and incubated at $37^{\circ} \mathrm{C}$ in a $5 \% \mathrm{CO}_{2}$ and $95 \%$ air humidified atmosphere in a $\mathrm{CO}_{2}$ cell incubator for $24 \mathrm{~h}$, followed by treatment with a final concentration of $1 \mu \mathrm{M}$ bFGF (NUPTEC). The bFGF-binding component was added to medium at various doses of $0,5,25,50$ and $100 \mu \mathrm{g} / \mathrm{ml}$ (final concentration) along with bFGF. Morphology of the cells was 
visualized using a Leica DM3000B microscope (Leica Microsystems GmbH, Wetzlar, Germany; magnification, x200) and images were captured using LAS software (version 4.2; Leica Microsystems $\mathrm{GmbH}$ ) and the length of 150 neurites was measured randomly for each sample at day 1, 2, 3, 4 and 5, respectively.

Cytotoxicity assay of bFGF-binding components. SH-SY5Y, Hep G2 and HUVEC cells $\left(1 \times 10^{4}\right)$ were plated into 96-well plates in triplicate and incubated at $37^{\circ} \mathrm{C}$ for $24 \mathrm{~h}$ as aforementioned. SH-SY5Y and Hep G2 cells were cultured in DMEM while HUVEC cells were cultured in ECM. Cells were then treated with bFGF-binding component at various doses of 0,5 , 25, 50 and $100 \mu \mathrm{g} / \mathrm{ml}$ (final concentration), respectively. Cell viability was determined using the MTT Cell Proliferation and Cytotoxicity Assay kit after $24 \mathrm{~h}$ treatment.

Reverse transcription-polymerase chain reaction (RT-PCR) assay. Gene expression of caspase- 3 and caspase- 8 was detected by RT-PCR analysis. SH-SY5Y cells were plated into a 6-well plate (Corning, Inc.) at an initial density of $1.0 \times 10^{5}$ cells/well. After $24 \mathrm{~h}$, cells were treated with bFGF-binding component at various doses of $0,5,25$ and $50 \mu \mathrm{g} / \mathrm{ml}$ (final concentration). Total RNAs were extracted by TRIzol reagent (Thermo Fisher Scientific, Inc.) and reverse-transcribed into cDNAs by FastQuant RT kit (Tiangen Biotech, Beijing, China), according to the manufacturer's protocol. Primers for caspase-3 (accession no. BC016926; www.ncbi.nlm.nih.gov), caspase-8 (accession no. AH007578; www.ncbi.nlm.nih.gov) and $\beta$-actin (accession no. DQ407611.1; www.ncbi.nlm.nih.gov) were designed and synthesized by Sangon (Biotech, Co., Ltd.) for RT PCR analysis (Table I). The PCRs were performed at $95^{\circ} \mathrm{C}$ for $2 \mathrm{~min}$, followed by 25 cycles of denaturing at $95^{\circ} \mathrm{C}$ for $15 \mathrm{sec}$, annealing at $61^{\circ} \mathrm{C}$ for $15 \mathrm{sec}$ and extending at $72^{\circ} \mathrm{C}$ for $45 \mathrm{sec}$. The PCR products were analyzed on $1 \%$ agarose gels and signal intensities were quantified by Quantity One (version 4.5; Bio-Rad Laboratories, Inc., Hercules, CA, USA).

Western blot analysis. SH-SY5Y cells were cultured and treated as aforementioned. After $24 \mathrm{~h}$, cells were collected with ice-cold PBS to $1.5 \mathrm{ml}$ centrifuge tubes, and centrifuged at $4^{\circ} \mathrm{C}$ and $200 \mathrm{x} g$ for $5 \mathrm{~min}$. The supernatant was discarded and collected cells were immediately lysed with lysis buffer (20 mM sucrose, $1 \mathrm{mM}$ EDTA, $20 \mu \mathrm{M}$ Tris-HCl, $\mathrm{pH} 7.2$, $1 \mathrm{mM}$ DTT, $10 \mathrm{mM} \mathrm{KCl}, 1.5 \mathrm{mM} \mathrm{MgCl}_{2}$, containing $1 \mathrm{mM}$ phenylmethanesulfonyl fluoride, PMSF). Lysed cells were then centrifuged at $4^{\circ} \mathrm{C}, 13,400 \times \mathrm{g}$ for $10 \mathrm{~min}$ and total protein was collected. Protein concentrations were determined to normalize different samples using Pierce BCA Protein kit (Thermo Fisher Scientific, Inc.), following the instructions. Total proteins were then loaded to $12 \%$ SDS-PAGE gel and electrophoresed for $40 \mathrm{~min}$ at $110 \mathrm{~V}$ and then transferred to a polyvinylidene fluoride (PVDF) membrane (Bio-Rad Laboratories, Inc.). The membrane was then blocked with 5\% skim milk, and incubated with the anti-caspase-3 (cat. no. ER30804; $1: 2,000$ ) or anti-caspase-8 (cat. no. ET1603-16; 1:2,000) primary antibodies (Hua'an Biotech, Hangzhou, China), and goat anti-rabbit IgG secondary antibodies (HRP-conjugated; cat. no. HA1001-100; 1:2,000; Hua'an Biotech), respectively.
Table I. Primers used in reverse transcription-polymerase chain reaction.

\begin{tabular}{ll}
\hline Primers & \multicolumn{1}{c}{ Sequences } \\
\hline $\begin{array}{c}\text { Caspase-3 } \\
\text { Forward } \\
\text { Reverse }\end{array}$ & CTGGACTGCGGTATTGAGAC \\
Caspase-8 & \\
Forward & CTGCAGAGGGAACCTGGTACATCC \\
Reverse & CATCAATCAGAAGGGAAGA \\
$\beta$-actin & \\
Forward & GATCATTGCTCCTCCTGAG \\
Reverse & ACTCCTGCTTGCTGATCCA \\
\hline
\end{tabular}

The target proteins were visualized using an enhanced chemiluminescence detection system (Tiangen Biotech).

Statistical analysis. Significance of differences between treatments and control were analyzed by analysis of variance using SPSS 17.0 (SPSS, Inc., Chicago, IL, USA) and considered significant at $\mathrm{P}<0.05$.

\section{Results}

Different pattern of components from FTV and DTV. By HPLC analysis, no significant differences in soluble fractions were identified between FTV and DTV on chromatography beyond $15 \mathrm{~min}$ retention time, although there were a number of chromatographic peaks showing difference in peak area (Fig. 1). However, there was an apparent difference between FTV and DTV within the first 15 min retention time. Particularly, FTV had three much larger peaks than DTV, and one large peak that was not observed in DTV within the first 5 min retention time (Fig. 1), indicating that FTV had more polar molecules than DTV.

Different cytotoxicity of components from FTV and DTV. Based on different patterns of components from FTV and DTV (Fig. 1), cytotoxicity of soluble fractions from FTV and DTV was compared in human SH-SY5Y cells to establish a link between HPLC chromatography and cytotoxicity. MTT assay demonstrated that cell survival decreased in SH-SY5Y cells treated by soluble fractions from FTV and DTV in a dose-dependent manner, indicating the cytotoxicity of FTV and DTV. However, FTV had a more significant cytotoxicity compared with DTV $(\mathrm{P}=0.15,0.0089,0.0024,0.0019,0.0056$, 0.0027 and 0.0014 at concentrations $0,0.1625,0.325,0.75$, $1.5,3$ and $6 \mathrm{mg} / \mathrm{ml}$, respectively; Fig. 2A). Alternatively, the cytotoxicity was also compared in EGFP-expressing SH-SY5Y cells. As fluorescence-imaged in Fig. 2B, FTV and DTV demonstrated cytotoxicity as compared with controls, however, FTV was more cytotoxic compared with DTV.

Protein components of toad venom and their cytotoxicity. According to HPLC analysis of soluble fractions of toad venom, the main difference between FTV and DTV was polar 

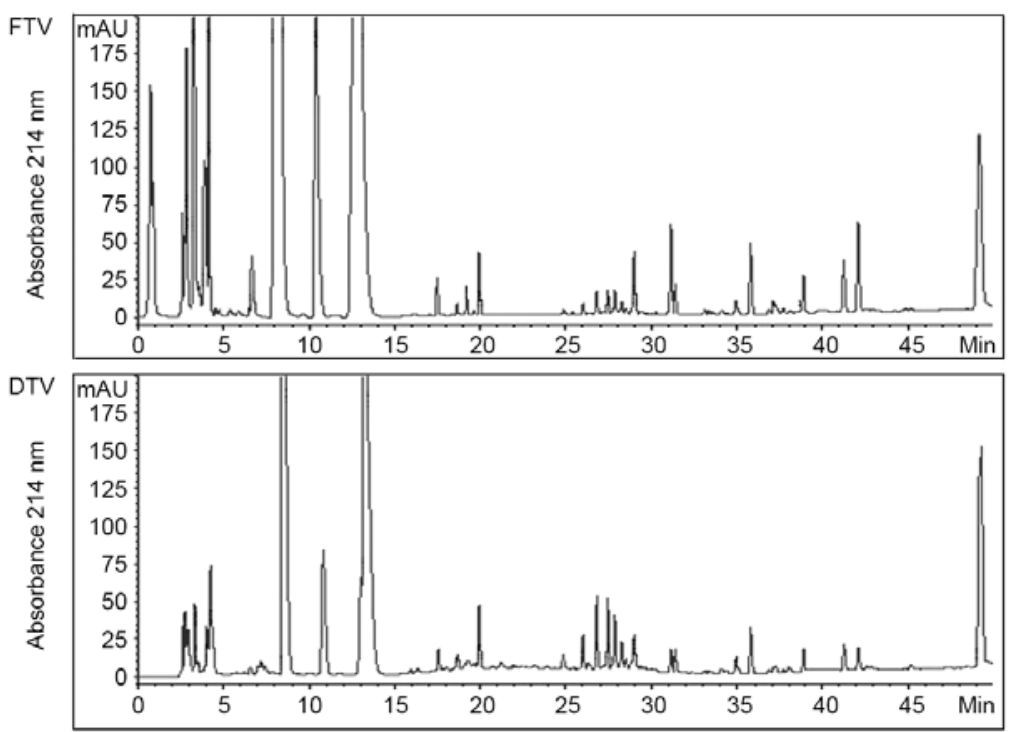

Figure 1. High performance liquid chromatography analysis of soluble fractions from FTV and DTV. Data show one of similar results from two independent experiments. FTV, fresh toad venom; DTV, dried toad venom.

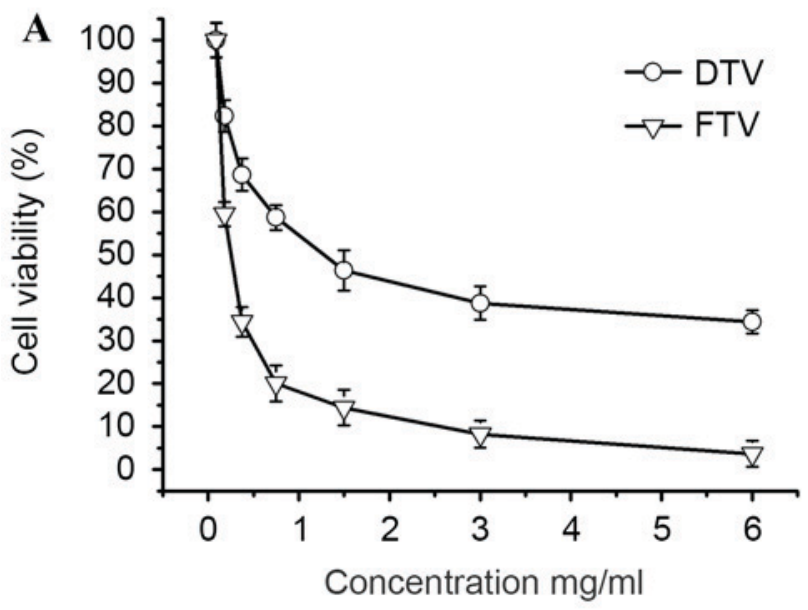

B

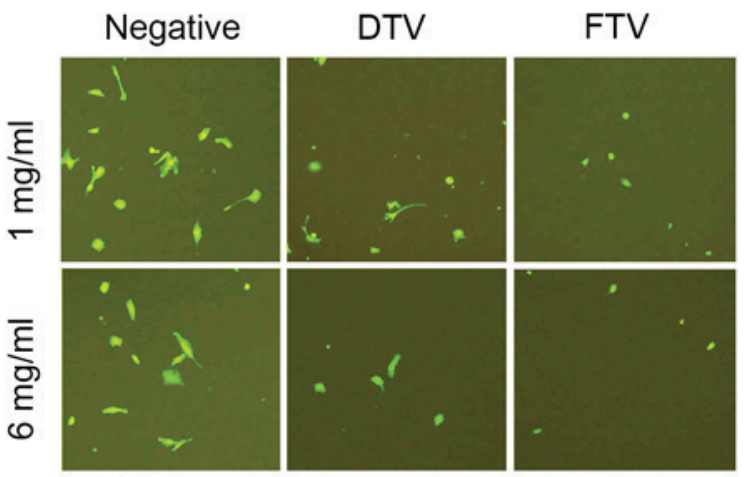

Figure 2. Cytotoxicity of soluble fractions from FTV and DTV. (A) Cytotoxicity of FTV and DTV in human SH-SY5Y cells determined by MTT assay. Data show the mean \pm standard error from three independent experiments. (B) Cytotoxicity of FTV and DTV in EGFP-expressing SH-SY5Y cells imaged by an inverted fluorescence microscope. Data show one of similar results from three independent experiments. Scale bar, $200 \mu \mathrm{m}$. FTV, fresh toad venom; DTV, dried toad venom.

molecular components (Fig. 1). Water-soluble protein/peptide is one type of highly polar biomolecules. Thus, water-soluble protein patterns were compared between FTV and DTV by SDS-PAGE analysis. As shown in Fig. 3A, FTV had more water-soluble protein bands than DTV, consistent with the evidence that FTV had more and larger peaks on HPLC chromatography compared with DTV within the first 5 min of retention time (Fig. 1). Subsequent protein analysis demonstrated that soluble fraction of FTV has a significantly higher protein level than DTV $(\mathrm{P}=0.0025$ and $\mathrm{P}=0.0064$, respectively; Fig. 3B).

Furthermore, to determine whether difference in water-soluble protein component of toad venom contributed to the cytotoxicity, protein fractions were isolated from soluble fractions of FTV and DTV, and the cytotoxicity was investigated in human SH-SY5Y cells. Consistent with the aforementioned results that FTV demonstrated a higher cytotoxicity than DTV (Fig. 2), FTV was more toxic to SH-SY5Y cells than DTV $(\mathrm{P}=0.21,0.0072,0.0055,0.0031$, $0.0021,0.0051$ and 0.0060 and concentrations $0,0.1625$, $0.325,0.75,1.5,3$ and $6 \mathrm{mg} / \mathrm{ml}$, respectively; Fig. 3C). In parallel to this observation, the protein fraction of FTV (FTV proteins) was also more toxic to cells than the protein fraction of DTV (DTV proteins) ( $\mathrm{P}=0.21,0.0072,0.0055,0.0031$, $0.0021,0.0051$ and 0.0060 and $0,0.1625,0.325,0.75,1.5$, 3 and $6 \mathrm{mg} / \mathrm{ml}$, respectively), and notably, the latter revealed only slight toxicity (Fig. 3C), suggesting that protein fraction is involved in the cytotoxicity of toad venom and toxic proteins only retained in FTV.

Identification of bFGF-binding components from FTV. bFGF is one of the biomarkers in angiogenesis for cancer metastasis. In order to identify anti-tumor components from FTV, a bFGF-immobilized affinity column was used to capture bFGF-binding components from FTV proteins, followed by identification of HPLC analysis. As shown in Fig. 4A, the bFGF-affinity column captured three specific peaks identified by HPLC chromatography, but the HSA-affinity control column did not. 
A

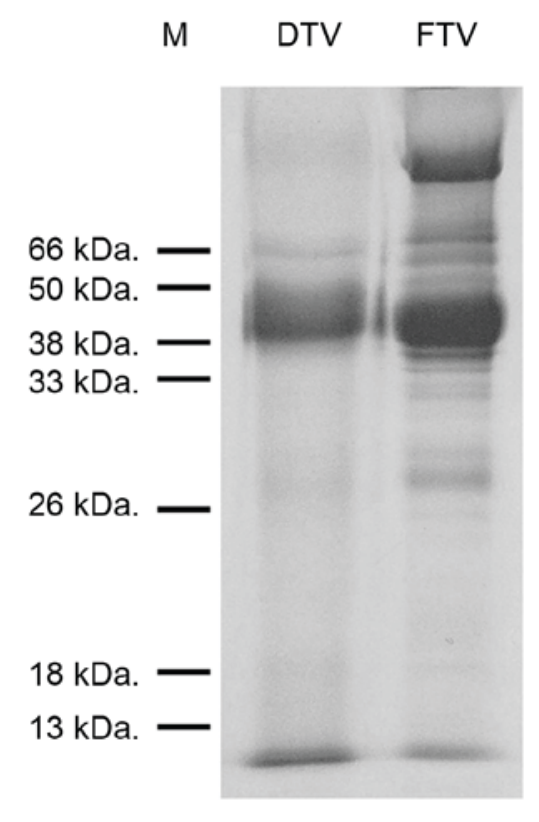

B
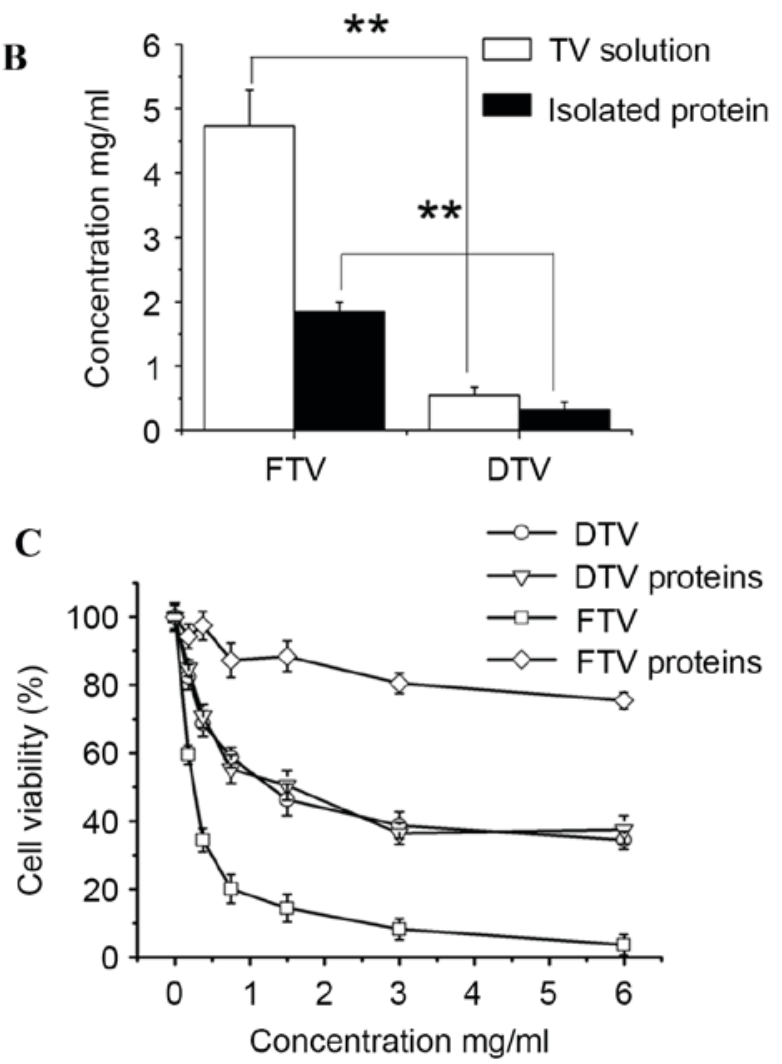

Figure 3. Cytotoxicity of water-soluble proteins isolated from FTV and DTV. (A) SDS-PAGE analysis of water-soluble proteins from FTV and DTV. Data show one of similar results from two independent experiments. (B) Content of total water-soluble proteins from FTV and DTV. (C) Cytotoxicity of water-soluble proteins isolated from FTV and DTV. Data show mean \pm standard error from three independent experiments. ${ }^{* *} \mathrm{P}<0.01$. M, marker; TV, toad venom; FTV, fresh toad venom; DTV, dried toad venom.

A
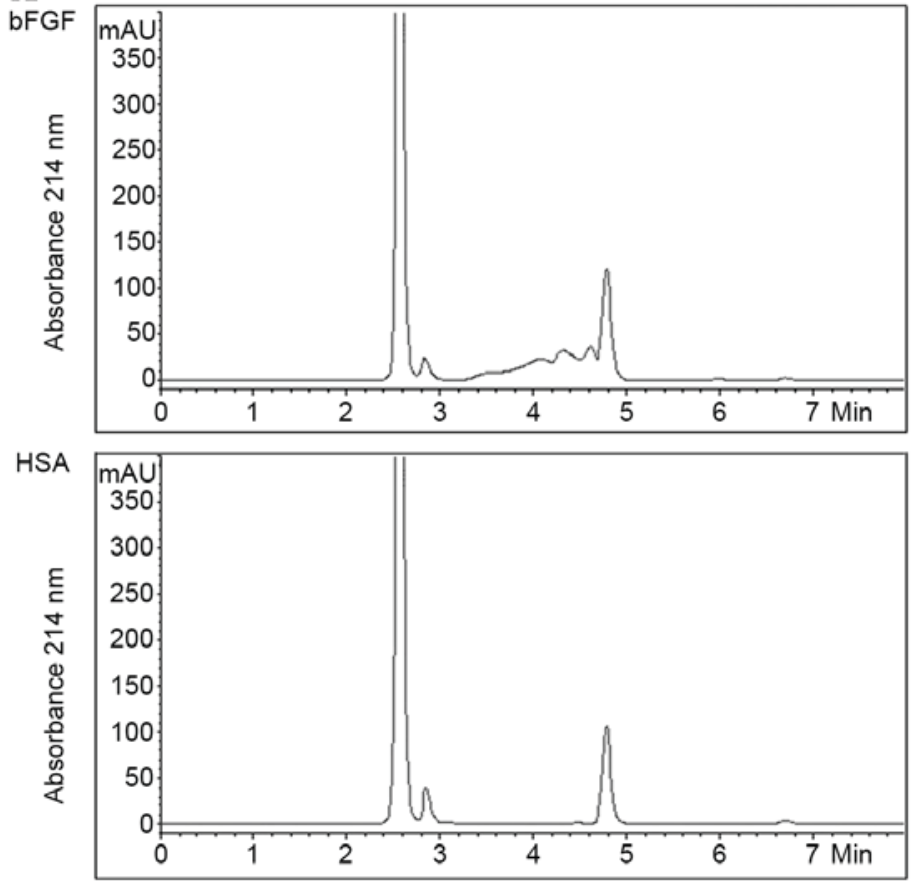

B

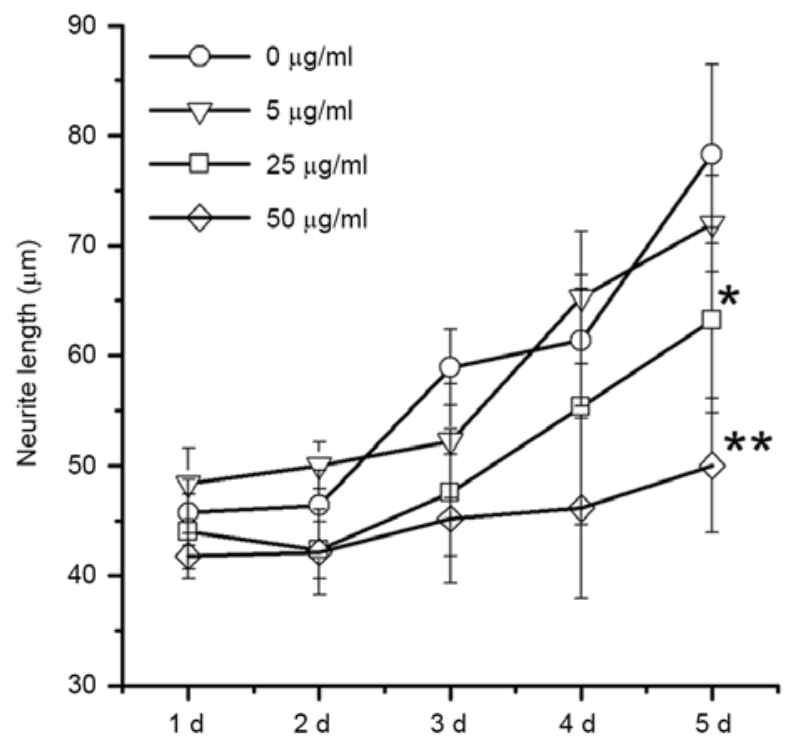

Figure 4. High performance liquid chromatography analysis and activity of bFGF-binding peptides from FTV. (A) Three chromatographic peaks were identified from eluted components of bFGF-affinity column loaded with the soluble fraction from FTV. Elute from HSA-affinity column loaded with soluble fraction from FTV was used as a negative control. Data show one of similar results from two independent experiments. (B) bFGF-induced neurite outgrowth of SH-SY5Y was inhibited by bFGF-binding components extracted from FTV. ${ }^{*} \mathrm{P}<0.05 \mathrm{vs} .0 \mu \mathrm{g} / \mathrm{ml}(\mathrm{P}=0.028),{ }^{* *} \mathrm{P}<0.01 \mathrm{vs} .0 \mu \mathrm{g} / \mathrm{ml}(\mathrm{P}=0.0081)$. FTV, fresh toad venom; HAS, human serum albumin; bFGF, basic fibroblast growth factor. 
A

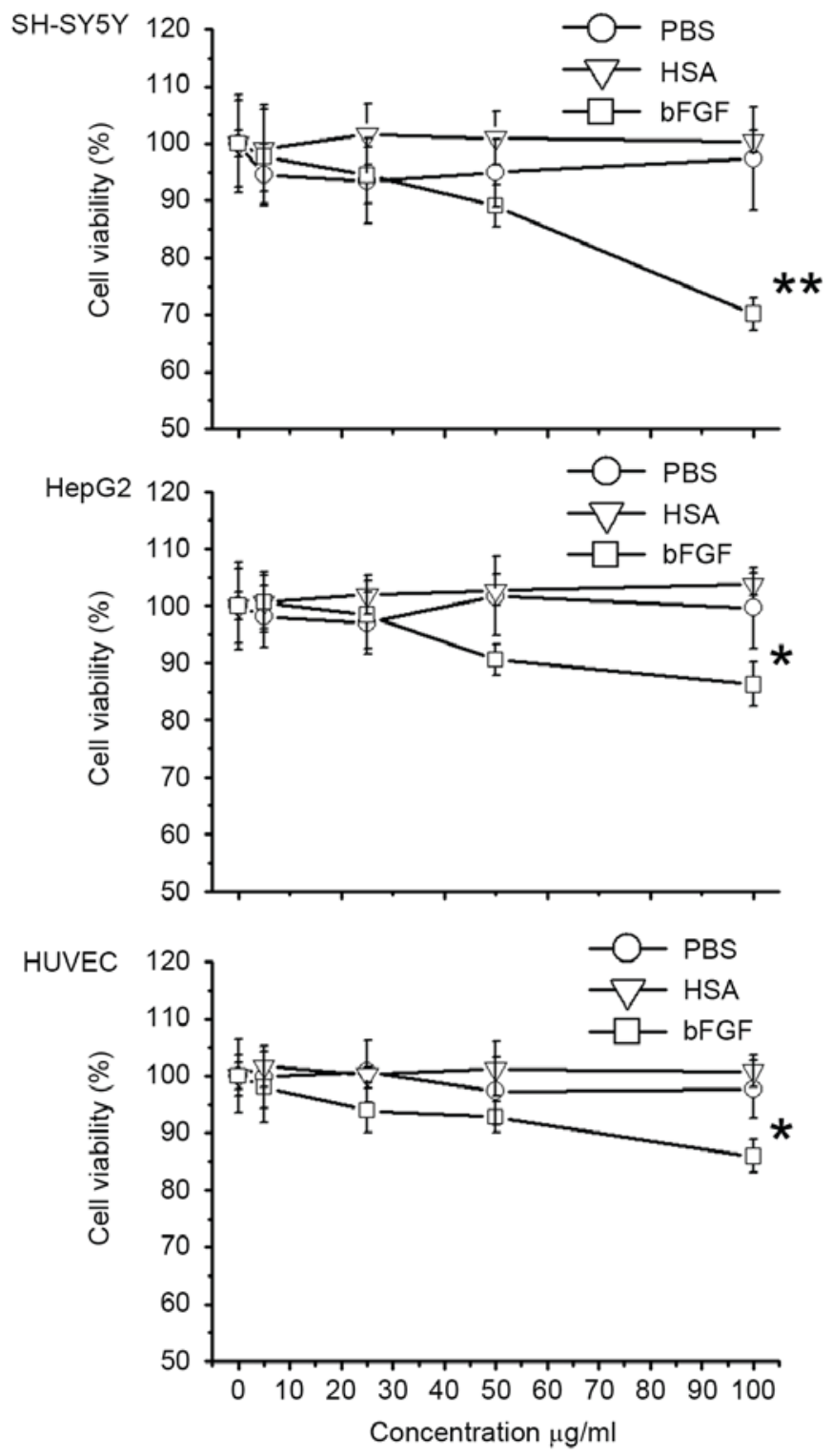

B
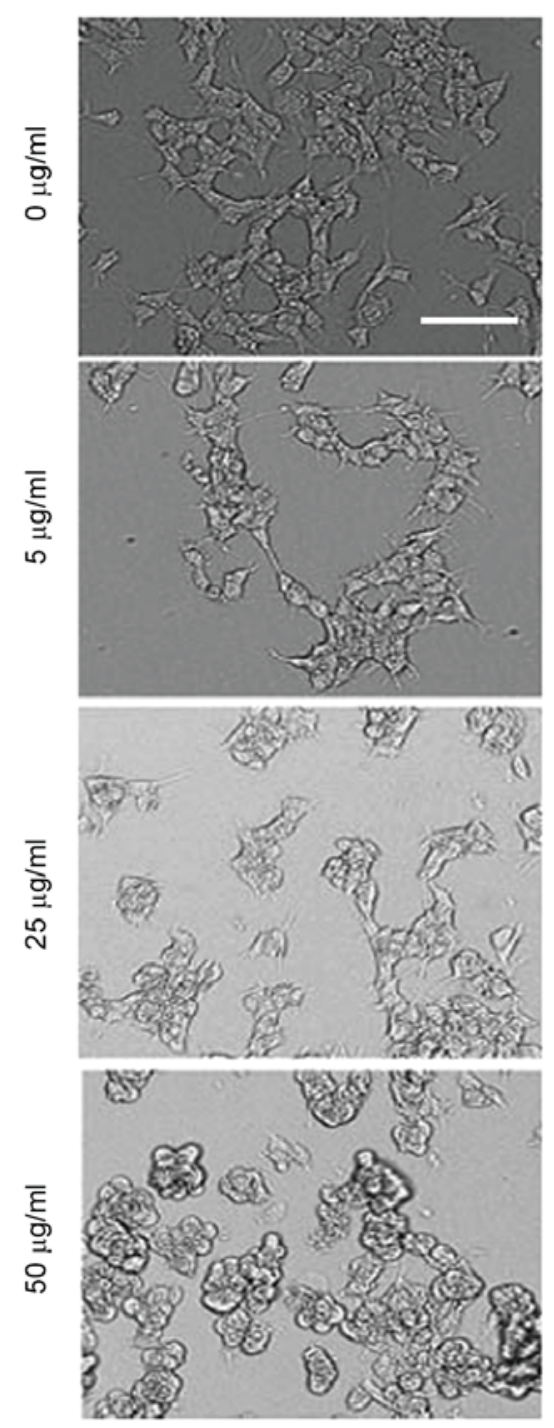

Figure 5. Viability of human SH-SY5Y cells reduced by bFGF-binding peptides. (A) Death of SH-SY5Y, Hep G2 and HUVEC cells was induced by bFGF-binding peptides extracted from FTV. (B) Morphology of SH-SY5Y cells following treatment by bFGF-binding peptides. Data show one of similar results from three independent experiments. ${ }^{* *} \mathrm{P}<0.01(\mathrm{P}=0.0014),{ }^{*} \mathrm{P}<0.05 \mathrm{vs} .0 \mu \mathrm{g} / \mathrm{ml}$ bFGF-binding peptide $(\mathrm{P}=0.031$ in HepG2 and $\mathrm{P}=0.035$ in HUVEC cells). Data show mean \pm standard error from three independent experiments.

To verify the activity of bFGF-binding components of FTV, eluates from the bFGF-affinity column were used to prohibit bFGF-induced neurite outgrowth of SH-SY5Y cells. Data revealed that the neurite outgrowth of human SH-SY5Y cells induced by bFGF is significantly prohibited by bFGF-binding components from FTV in a dose-dependent manner compared with the control $(\mathrm{P}=0.028$ and 0.0081 at concentrations 25 and $50 \mu \mathrm{g} / \mathrm{ml}$, respectively; Fig. 4B).

Apoptosis induced by bFGF-binding components. In the present study, the cytotoxicity of bFGF-binding components to human SH-SY5Y, Hep G2 and HUVEC cells was shown to be specific $(\mathrm{P}=0.0014,0.031$ and 0.035 for SH-SY5Y, HepG2 and HUVEC cells, respectively), since PBS and HSA-binding components did not show cytotoxicity (Fig. 5A). Particularly in the SH-SY5Y cells, the morphology of cells was greatly affected following treatment with bFGF-binding components (Fig. 5B). To further investigate the mechanism of cytotoxicity induced by bFGF-binding components, gene and protein expression of caspase-3 and caspase-8 (two biomarkers for apoptosis) was studied by analysis of mRNA and protein level in SH-SY5Y cells treated with bFGF-binding components. Data from RT-PCR, as well as western blot analysis, revealed that gene $(\mathrm{P}=0.0075,0.0043$ and 0.0031 at concentrations 5,25 and $50 \mathrm{mg} / \mathrm{ml}$, respectively, vs. the Cap- 3 control; $\mathrm{P}=0.022,0.0077$ and 0.0059 at concentrations 5,25 and $50 \mathrm{mg} / \mathrm{ml}$, respectively, vs. the Cap- 8 control) and protein ( $\mathrm{P}=0.13,0.0037$ and 0.0023 at concentrations 5,25 and $50 \mathrm{mg} / \mathrm{ml}$, respectively, vs. the Cap-3 control; $\mathrm{P}=0.0090,0.0041$ and 0.0055 at concentrations 5,25 and $50 \mathrm{mg} / \mathrm{ml}$, respectively, vs. the Cap- 8 control) expression of caspase- 3 and caspase- 8 were significantly upregulated by bFGF-binding components in a dose-dependent manner 
A

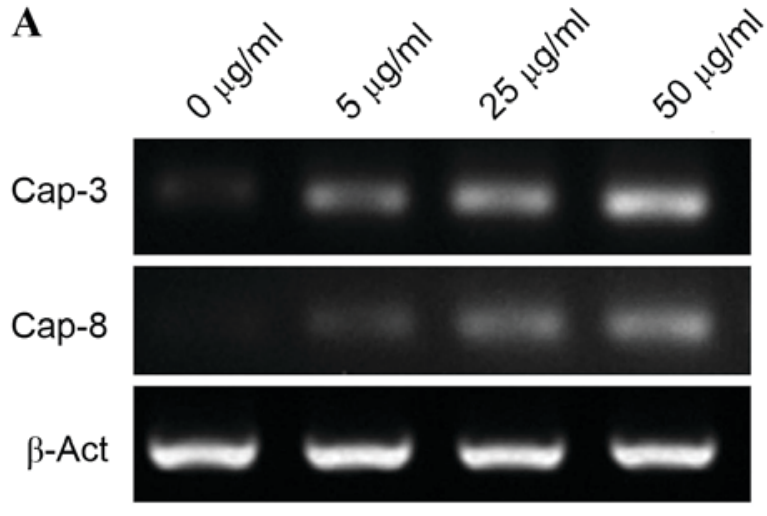

C

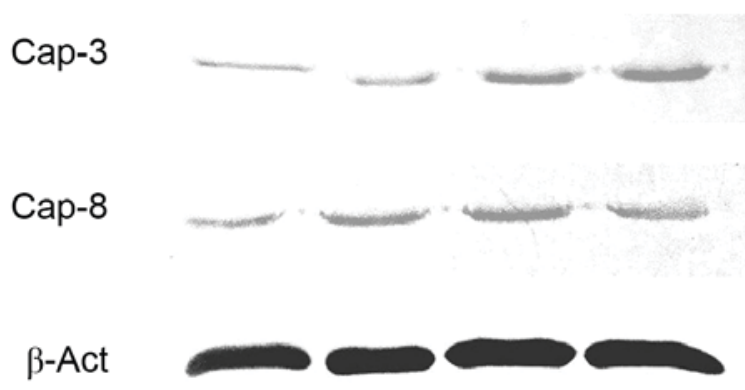

B

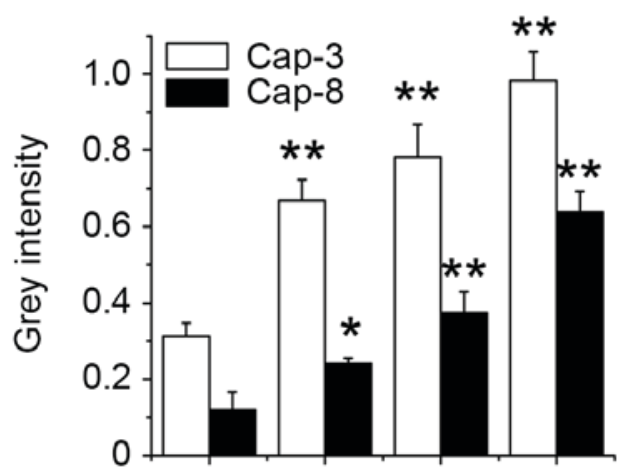

D

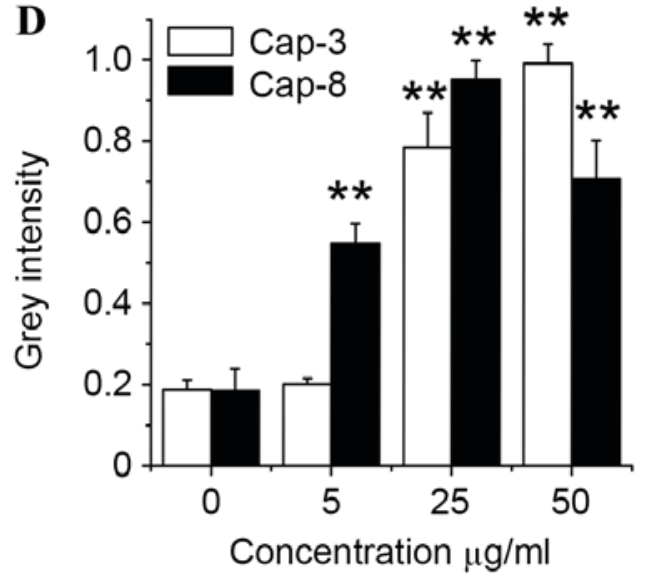

Figure 6. Apoptosis related molecules in SH-SY5Y treated by bFGF-binding peptides. (A) Expression of caspase-3 and caspase-8 genes was upregulated by bFGF-binding peptides extracted from FTV, as detected by RT-PCR analysis. (B) Quantification of mRNA levels of caspase-3 and caspase-8 following normalization to $\beta$-actin. (C) Expression of caspase-3 and caspase- 8 proteins was upregulated by bFGF-binding peptides extracted from FTV, as detected by western blot analysis. (D) Quantification of protein levels of caspase- 3 and caspase- 8 following normalization to $\beta$-actin. ${ }^{* *} \mathrm{P}<0.01$ vs. control. ${ }^{*} \mathrm{P}<0.05$ vs. control. Data show mean \pm standard error from three independent experiments. Cap-3, caspase-3; Cap-8, caspase-8; $\beta$-Act, $\beta$-actin.

(Fig. 6), suggesting that bFGF-binding components can induce cytotoxicity, possibly via activation of apoptosis in human SH-SY5Y cells.

\section{Discussion}

Anti-tumor peptides secreted from the skin of frogs and toads have been extensively reported and they give a promising progress in cancer research and clinical practice $(14,15,19,30)$. However, these peptides exhibit a high diversity in different species, including Pipidae and Discoglossidae. B. gargarizans is one of the most important species of Bufonidae in China, and the majority of studies are focused on the anti-tumor activity of small molecular components $(4,6,7,13)$. It has not been reported that this species has anti-tumor peptides secreted from skin glands. In the present study, components from B. gargarizans that contributed to the inhibition of proliferation of SH-SY5Y neuroblastoma cells were identified.

DTV has been used as a traditional medicine in China for thousands of years (1). In the present study, DTV was identified to possess fewer peptides than FTV, since treatment may be harmful for peptides when FTV is prepared for DTV. This is supported by the observation in the present study that FTV had more protein bands and components than DTV, as evidenced by HPLC and SDS-PAGE analysis. Along with the difference in protein components, FTV had more significant cytotoxicity in SH-SY5Y neuroblastoma cells than DTV and isolated proteins/peptides from FTV were more cytotoxic to tumor cells than those from DTV.

To identify active peptides from FTV, a bFGF-immobilized affinity column was used to capture bFGF-binding components from FTV protein fractions, and three potential peptides that could inhibit the proliferation of bFGF-dependent cells including HUVEC and SH-SY5Y, were identified $(31,32)$. In parallel to the inhibition of cell proliferation, these bFGF-binding components could also upregulate the gene and protein expression of caspase- 3 and caspase- 8 in tumor cells, suggesting that the cytotoxicity induced by bFGF-binding components possibly came from the activation of apoptosis, and that the anti-tumor activity of bFGF-binding components isolated from FTV was contributed by inhibition of bFGF activity and down-regulation of bFGF gene expression. This is consistent with bFGF being markedly involved in tumor growth (31-33).

\section{Acknowledgements}

The present study was supported by the startup fund (grant no. 2012FR017) from Zhejiang A\&F University in China, Zhejiang Provincial Natural Science Foundation (grant no. LQ14H280007) in China, and Prior project (grant no. T12B13292014) from Hangzhou Hygiene Bureau Zhejiang, China. 


\section{References}

1. The State Pharmacopoeia Commission of PR China: Pharmacopoeia of the People's Republic of China. 2010 edition. Vol. 1. Chemical Industry Publishing House, Beijing, pp360-360, 2010.

2. Meng Z, Yang P, Shen Y, Bei W, Zhang Y, Ge Y, Newman RA, Cohen L, Liu L, Thornton B, et al: Pilot study of huachansu in patients with hepatocellular carcinoma, nonsmall-cell lung cancer, or pancreatic cancer. Cancer 115: 5309-5318, 2009.

3. Zhang SJ, Zhang YT, Zhao JH, Shen LN, Shi F and Feng NP: Preparation and in vitro anti-tumor properties of toad venom extract-loaded solid lipid nanoparticles. Pharmazie 68: 653-660, 2013.

4. Qiao L, Huang YF, Cao JQ, Zhou YZ, Qi XL and Pei YH: One new bufadienolide from Chinese drug 'Chan'Su'. J Asian Nat Prod Res 10: 233-237, 2008.

5. Li J, Ma X, Li F, Wang J, Chen H, Wang G, Lv X, Sun C and Jia J: Preparative separation and purification of bufadienolides from Chinese traditional medicine of ChanSu using high-speed counter-current chromatography. J Sep Sci 33: 1325-1330, 2010.

6. Zhang DM, Liu JS, Deng LJ, Chen MF, Yiu A, Cao HH, Tian HY, Fung KP, Kurihara H, Pan JX and Ye WC: Arenobufagin, a natural bufadienolide from toad venom, induces apoptosis and autophagy in human hepatocellular carcinoma cells through inhibition of PI3K/Akt/mTOR pathway. Carcinogenesis 34: 1331-1342,2013.

7. Zhu Z, Li E, Liu Y, Gao Y, Sun H, Wang Y, Wang Z, Liu X, Wang $Q$ and Liu Y: Bufalin induces the apoptosis of acute promyelocytic leukemia cells via the downregulation of survivin expression. Acta Haematol 128: 144-150, 2012.

8. Hong SH, Kim GY, Chang YC, Moon SK, Kim WJ and Choi YH: Bufalin prevents the migration and invasion of T24 bladder carcinoma cells through the inactivation of matrix metalloproteinases and modulation of tight junctions. Int J Oncol 42: 277-286, 2013

9. Chen YY, Lu HF, Hsu SC, Kuo CL, Chang SJ, Lin JJ, Wu PP, Liu JY, Lee CH, Chung JG and Chang JB: Bufalin inhibits migration and invasion in human hepatocellular carcinoma SK-Hep1 cells through the inhibitions of NF- $\kappa B$ and matrix metalloproteinase-2/-9-signaling pathways. Environ Toxicol 30 74-82, 2015.

10. Zhai XF, Fang FF, Liu Q, Meng YB, Guo YY and Chen Z: MiR-181a contributes to bufalin-induced apoptosis in PC-3 prostate cancer cells. BMC Complement Altern Med 13: 325, 2013.

11. Miller YE: Bombesin-like peptides: From frog skin to human lung. Am J Respir Cell Mol Biol 3: 189-190, 1990.

12. Simmaco M, Severini C, De Biase D, Barra D, Bossa F, Roberts JD, Melchiorri P and Erspamer V: Six novel tachykininand bombesin-related peptides from the skin of the Australian frog Pseudophryne guntheri. Peptides 11: 299-304, 1990.

13. Lee WH, Li Y, Lai R, Li S, Zhang Y and Wang W: Variety of antimicrobial peptides in the Bombina maxima toad and evidence of their rapid diversification. Eur J Immunol 35: 1220-1229, 2005.

14. King JD, Leprince J, Vaudry H, Coquet L, Jouenne T and Conlon JM: Purification and characterization of antimicrobial peptides from the Caribbean frog, Leptodactylus validus (Anura: Leptodactylidae). Peptides 29: 1287-1292, 2008.

15. Bevins CL and Zasloff M: Peptides from frog skin. Annu Rev Biochem 59: 395-414, 1990.

16. Bechinger B, Zasloff $M$ and Opella SJ: Structure and orientation of the antibiotic peptide magainin in membranes by solid-state nuclear magnetic resonance spectroscopy. Protein Sci 2: 2077-2084, 1993.

17. Westerhoff HV, Zasloff M, Rosner JL, Hendler RW, De Waal A, Vaz Gomes A, Jongsma PM, Riethorst A and Juretić D: Functional synergism of the magainins PGLa and magainin-2 in Escherichia coli, tumor cells and liposomes. Eur J Biochem 228 257-264, 1995.
18. Ohsaki Y, Gazdar AF, Chen HC and Johnson BE: Antitumor activity of magainin analogues against human lung cancer cell lines. Cancer Res 52: 3534-3538, 1992.

19. Baker MA, Maloy WL, Zasloff M and Jacob LS: Anticancer efficacy of Magainin2 and analogue peptides. Cancer Res 53: 3052-3057, 1993

20. Giacometti A, Ghiselli R, Cirioni O, Mocchegiani F, D'Amato G, Orlando F, Sisti V, Kamysz W, Silvestri C, Naldoski P, et al: Therapeutic efficacy of the magainin analogue MSI-78 in different intra-abdominal sepsis rat models. J Antimicrob Chemother 54: 654-660, 2004

21. Shin SY, Kang JH, Jang SY, Kim Y, Kim KL and Hahm KS: Effects of the hinge region of cecropin A(1-8)-magainin 2(1-12), a synthetic antimicrobial peptide, on liposomes, bacterial and tumor cells. Biochim Biophys Acta 1463: 209-218, 2000.

22. Takeshima K, Chikushi A, Lee KK, Yonehara S and Matsuzaki K: Translocation of analogues of the antimicrobial peptides magainin and buforin across human cell membranes. J Biol Chem 278: 1310-1315, 2003.

23. Gibson BW, Tang DZ, Mandrell R, Kelly M and Spindel ER: Bombinin-like peptides with antimicrobial activity from skin secretions of the Asian toad, Bombina orientalis. J Biol Chem 266: 23103-23111, 1991.

24. Kubo H, Cao R, Brakenhielm E, Makinen T, Cao Y and Alitalo K: Blockade of vascular endothelial growth factor receptor-3 signaling inhibits fibroblast growth factor-2-induced lymphangiogenesis in mouse cornea. Proc Natl Acad Sci USA 99: 8868-8873, 2002.

25. Demirkesen C, Büyükpinarbasili N, Ramazanoğlu R, Oğuz O, Mandel NM and Kaner G: The correlation of angiogenesis with metastasis in primary cutaneous melanoma: A comparative analysis of microvessel density, expression of vascular endothelial growth factor and basic fibroblastic growth factor. Pathology 38: 132-137, 2006

26. Huang J, Wu L, Tashiro S, Onodera S and Ikejima T: Fibroblast growth factor-2 suppresses oridonin-induced L929 apoptosis through extracellular signal-regulated kinase-dependent and phosphatidylinositol 3-kinase-independent pathway. J Pharmacol Sci 102: 305-313, 2006

27. Liu JF, Crepin M, Liu JM, Barritault D and Ledoux D: FGF-2 and TPA induce matrix metalloproteinase-9 secretion in MCF-7 cells through PKC activation of the Ras/ERK pathway. Biochem Biophys Res Commun 293: 1174-1182, 2002.

28. Suyama K, Shapiro I, Guttman M and Hazan RB: A signaling pathway leading to metastasis is controlled by N-cadherin and the FGF receptor. Cancer Cell 2: 301-314, 2002.

29. Qian Y, Zheng Y and Tiffany-Castiglioni E: Valproate reversibly reduces neurite outgrowth by human SY5Y neuroblastoma cells. Brain Res 1302: 21-33, 2009.

30. Ferreira PM, Lima DJ, Debiasi BW, Soares BM, Machado Kda C, Noronha Jda C, Rodrigues Dde J, Sinhorin AP, Pessoa C and Vieira GM Jr: Antiproliferative activity of Rhinella marina and Rhaebo guttatus venom extracts from Southern Amazon. Toxicon 72: 43-51, 2013

31. Li D, Wang H, Xiang JJ, Deng N, Wang PP, Kang YL, Tao J and $\mathrm{Xu}$ M: Monoclonal antibodies targeting basic fibroblast growth factor inhibit the growth of $\mathrm{B} 16$ melanoma in vivo and in vitro. Oncol Rep 24: 457-463, 2010.

32. Polec A, Fedorcsak P, Eskild A and Tanbo TG: The interplay of human chorionic gonadotropin (hCG) with basic fibroblast growth factor and adipokines on angiogenesis in vitro. Placenta 35: 249-253, 2014.

33. Xu Z, Shi H, Mei Q, Shen Y and Xu J: Effects of macrophage metalloelastase on the basic fibroblast growth factor expression and tumor angiogenesis in murine colon cancer. Dig Dis Sci 57: 85-91, 2012. 